\title{
A NOTE ON NAMES, ORTHOGRAPHY, AND PRONUNCIATION
}

In this book the term "Maya" is used as a noun to refer to the Maya people, ancient and modern, and as an adjective, as in "Maya books," "Maya pottery," or "Maya writing." When referring to languages, however, it is customary to use the term "Mayan," as in "the Mayan languages."

The names of some Maya cities were recorded at the time of the Spanish Conquest, so that "Chichen Itza" and "Mayapan" are original Maya names that are still used today. In the highlands, where the invading Spaniards were aided by armies from Central Mexico, many Maya place-names were translated into Nahuatl, the language of these Mexica or Aztec allies. As a result, Q'umarkaj, the K'iche Maya capital, is usually known as "Utatlan," its Nahuatl name. Many earlier Maya cities had been abandoned by the time of the Conquest, so their names were not recorded by Europeans. When the ruins of theses cities were rediscovered, they were often given new Spanish or Mayan names, such as El Mirador ("the lookout"), Piedras Negras ("black stones"), Tulum ("rampart”), Uaxactun ("eight stone”), or Tikal (probably from ti ak'al, "at the waterhole"). Today, however, the original names of a number of ancient cities have been rediscovered by the decipherment of Maya texts. As a result, we now know that the ruins of the city that became known in the eighteenth century as Palenque ("palisade") was called Lakamha' ("great water") by its original inhabitants.

The orthography for the various Mayan languages (see Chapter 3) was first worked out by Spanish clerics and scholars in the colonial period. This traditional orthography was in general use until recently. Today the Maya people have taken the lead in adopting a new orthography that more accurately expresses the sounds of their languages. This orthography is used in this book to refer to the Mayan languages, as in "K'iche" instead of "Quiché." The traditional orthography is retained in referring to established geographic place-names such as "Uaxactun" or "El Quiché" and to usage in the published literature.

Mayan vowels are pronounced as in Spanish; rough English equivalents for Mayan vowels would be:

$a$ as in $\mathrm{f} a$ ther

$e$ as in let

$i$ as in machine

$o$ as in forty

$u$ as in rule (but pronounced as an English $w$ before another vowel, as in $w o$ ).

Distinctions between long and short vowels have also been recognized from deciphered Maya texts. Long vowels are represented by doubled letters, as in Itzamnaaj. 
Consonants are also pronounced as in Spanish, although some need special mention:

ch as in church (Mayan chak)

$k$ as in keen (Mayan kan)

$h$ (soft) as in his (Mayan baah)

$j$ (hard $h$ ) as in Bach (Mayan ajaw)

ts as in nights (Mayan ts'ak)

$x$ as sh in she (Mayan Yaxchilan)

Mayan languages also distinguish glottalized from plain consonants; glottalized consonants have no Spanish or English equivalents. These are represented by an apostrophe, as in k'inich, to distinguish words like ch'ak (to chop) from chak ("great" or "red").

In contrast to its usual occurrence on the next to last syllable in both Spanish and Nahuatl, stress is generally on the final syllable in Mayan languages. Unlike most Mayan languages, Yukatek also has tonal differences, but these were not marked by most colonial lexicographers and are omitted here. In keeping with general practice, accents on Mayan and other indigenous words are not used in this book. Accent marks are used as needed in place names of Spanish origin (El Cerén) and in Hispanicized indigenous words, as in Departamento de Petén, Guatemala - otherwise Peten (Mayan for "island") is used to refer to the geographic area in the central lowlands of Guatemala.

This book employs the metric system for measurements, the standard in both science and in the countries having jurisdiction over the remains of Maya civilization. For those who want to use English measures, I meter $(\mathrm{m})=39.37$ inches, or 3.28 feet; I kilometer $(\mathrm{km})=0.62$ mile; I square kilometer $\left(\mathrm{km}^{2}\right)=0.38$ square miles. 
THE ANCIENT MAYA 
